\title{
PREDIKSI KENAIKAN HEAT RATE TURBIN UAP PADA PEMBANGKIT LISTRIK BERKAPASITAS 660 MW
}

\author{
Muhammad Sagaf* dan Saharul Alim \\ Jurusan Teknik Elektro Universitas Islam Nahdlatul Ulama \\ Jalan Taman Siswa (Pekeng) Tahunan Jepara \\ *Email: sagaf_mnwr@yahoo.com
}

\begin{abstract}
Abstrak
Kebutuhan energi listrik yang semakin meningkat harus diimbangi dengan peningkatan performance dan efisiensi dari pembangkit listrik untuk mengurangi jumlah sumber daya alam yang dikonversi menjadi energi listrik. Turbin heat rate merupakan salah satu indikator performance atau unjuk kerja dari Pembangkit Listrik Tenaga Uap (PLTU). Penelitian ini dilakukan dengan tujuan untuk mendapatkan prediksi nilai kenaikan turbin heat rate pada PLTU berkapasitas 660 MW dengan menggunakan metode regresi linear. Dari hasil penelitian didapatkan kenaikan turbin heat rate untuk Unit 3 sebesar 13,54 KJ/kWh per-tahun dan untuk Unit 4 sebesar 15,8 KJ/kWh per-tahun.
\end{abstract}

Kata kunci: performance, turbine heat Rate, regresi linear

\section{PENDAHULUAN}

Kebutuhan energi listrik merupakan kebutuhan yang mendasar dalam aktivitas manusia. Dan secara nasional semakin meningkat sejalan dengan pertumbuhan penduduk, kemajuan teknologi dan perkembangan dunia industri. Permasalahan yang terjadi adalah seiring dengan peningkatan kebutuhan energi listrik maka semakin tinggi pula kebutuhan sumber daya yang harus dikonversi menjadi energi listrik. Sehingga penerapan program efisiensi energi menjadi sebuah tuntutan yang harus dipenuhi untuk mengendalikan jumlah pemakaian dan eksploitasi terhadap sumber daya, baik dari sisi proses produksi maupun dari segi penggunaan energi listrik.

Pembangkit Listrik Tenaga Uap (PLTU) Tanjung Jati B merupakan sebagian dari pembangkit listrik swasta yang ada dan mempunyai 4 unit pembangkit listrik yang masing-masing berkapasitas 660 MW. Energi listrik yang dihasilkan digunakan untuk menyuplai listrik di wilayah Jawa, Madura dan Bali (Jamali) dengan kontribusi sekitar 12\%. Berdasarkan Rapat Alokasi Energi (RAE) PLN sampai bulan Juli 2019, PLTU Tanjung Jati B unit 3 dan 4 menempati urutan pertama dalam hal merit order. Merit order merupakan daftar unit pembangkit dengan urutan biaya operasi yang marginal, sudah termasuk pertimbangan : biaya start-up dan shut-down, minimum startup dan waktu keluar, kendala bahan bakar, serta kendala operasi lainnya.
Untuk menyuplai listrik di wilayah Jamali, dan menghasilkan merit order urutan pertama dengan biaya operasional terendah, unit pembangkit dilengkapi dengan peralatan yang mendukung dalam sistem PLTU secara keseluruhan dan pola operasi yang optimal. Salah satu peralatan utamanya adalah turbin uap. Yang berfungsi untuk mengubah energi panas yang dihasilkan oleh boiler menjadi energi mekanis atau putaran. Energi putaran dari turbin kemudian digunakan untuk memutar generator untuk membangkitkan listrik. PLTU Tanjung Jati B unit 3 dan 4 mulai beroperasi sejak commercial operation day (COD) pada Oktober tahun 2011 dan unit 4 COD pada bulan Januari 2012.

Performance atau unjuk kerja PLTU meliputi: heat rate atau tara kalor, efisiensi boiler, turbin-generator, UAT (Unit Auxiliary Transformer) atau pemakaian listrik untuk keperluan sendiri dan efisiensi plant atau pembangkit secara keseluruhan. Heat rate adalah ukuran dari thermal performance boilerturbine-generator yang dioperasikan secara gabungan sebagai suatu unit. Heat Rate didefinisikan sebagai jumlah dari energi bahan bakar yang dibutuhkan untuk menghasilkan sejumlah energi listrik selama waktu satu jam. Satuan Heat Rate adalah KJ/kWh. Dimana heat rate semakin meningkat dengan semakin bertambah umur suatu pembangkit listrik yang berbanding terbalik dengan efisiensinya, efisiensi akan semakin menurun dengan bertambahnya umur pembangkit listrik. Dengan fenomena seperti di atas maka sangat perlu 
dilakukan analisa terhadap perubahan performance pembangkit.

Tujuan penelitian ini adalah melakukan analisa performance pembangkit dengan menghitung perubahan nilai turbin heat rate mulai saat COD sampai dengan tahun terakhir untuk dapat digunakan dalam memprediksi kenaikan nilai turbine heat rate.

Sunarwo (2015) melakukan penelitian tentang heat rate pada turbin uap di PLTU Tanjung Jati B Unit 3 dengan berdasarkan performance test ke-1 sampai ke-4. Didapatkan nilai heat rate turbin terendah sebesar 7981,97 $\mathrm{KJ} / \mathrm{kWh}$ dengan efisiensi turbin $45,1 \%$, dan nilai heat rate turbine tertinggi 8043,12 $\mathrm{KJ} / \mathrm{kWh}$ dengan efisiensi turbin $44,75 \%$.

Jamaludin (2017) melakukan perhitungan daya dan efisiensi turbin uap pada unit 1 dan 2 di PLTU Banten 3 Lontar. Dari hasil penelitian disimpulkan bahwa perubahan daya dan efisiensi turbin untuk unit 1 dan 2 tidak mengalami perubahan yang signifikan. Penyebab perubahan antara lain karena perubahan turbin heat rate, tidak sempurna pembakaran batu bara, karakteristik batu bara, penurunan beban, lamanya waktu pemeliharaan, kesalahan operasi dan perawatan serta faktor yang lain.

Karakurt (2017) melakukan penelitian tentang performance turbin uap yang dioperasikan pada beban parsial. Hasil penelitian menunjukkan bahwa performance turbin uap maupun pembangkit berkurang ketika pembangkit listrik beroperasi pada kondisi beban parsial.

Dari hasil penelitian Dab (2017) didapatkan bahwa monitoring dan ketepatan nilai heat rate sangat terkait langsung terhadap profit pembangkit. Dan semakin tinggi nilai heat rate, maka semakin tidak efisien pembangkit tersebut.

Berdasarkan penelitian Rana (2013) mengenai energi dan exergy extraction cum back pressure steam turbin dihasilkan bahwa kondisi operasi turbin pada $85 \%$ maximum continuous rating (MCR) menunjukkan perbaikan hebat rate sebesar $17,01 \mathrm{KJ} / \mathrm{kWh}$, penurunan konsumsi batu bara $16,46 \mathrm{~kg} / \mathrm{jam}$ penurunan emisi $\mathrm{CO}_{2}$ sebesar $26,89 \mathrm{~kg} / \mathrm{jam}$, emisi SO2 berkurang 0,62 kg/jam, ash yang dihasilkan berkurang $41.47 \mathrm{~kg} / \mathrm{hari}$ dibandingkan pada kondisi operasi $70 \%$ MCR.

Turbine heat rate dapat dihitung dengan persamaan dasar sebagai berikut (ASME, 2004):
$\mathbf{H R}_{\mathbf{T}}=\frac{\text { Net Heat to the Cycle }}{\text { Output }}$

Turbine heat rate pada $100 \%$ ECR dihitung menggunakan rumus sebagai berikut (Toshiba, 2011):

$\mathbf{H R}_{\mathbf{T}}=((M 1 \times H 1)-(M 1+M m u) \times$ $H f w+M 2 \times(H 3-H 2)+M i s \times(H f w-$ His $)) /(P g-P e x c)$

dengan:

$$
\mathbf{M}_{1}=M f+M i s-M m u
$$

$\mathbf{M}_{2}=M 1-G s 2-G 11-G 12-G 22-$ G23-Mex7-Mex6

$$
\mathbf{M}_{\mathbf{m u}}=M m-M c s-M d s-M b d
$$

dimana:

$\mathrm{HR}_{\mathrm{T}}$ : heat rate turbine $(\mathrm{KJ} / \mathrm{kWh})$

$\mathrm{Pg}$ : output turbine generator $(\mathrm{kW})$

Pece : Generator excitation power $\quad(\mathrm{kW})$

M1 : Laju aliran massa main steam pada inlet main stop valve $(\mathrm{kg} / \mathrm{h})$

M2 : Laju aliran massa cold reheat steam pada inlet reheater $(\mathrm{kg} / \mathrm{h})$

$\mathrm{Mmu}$ : Laju aliran massa make up water $(\mathrm{kg} / \mathrm{h})$

Mis : Laju aliran massa Super heater spray water $(\mathrm{kg} / \mathrm{h})$

Mf : Laju aliran massa feed Water $(\mathrm{kg} / \mathrm{h})$

Mex7 : Laju aliran massa extraction steam ke $\mathrm{HP \# 7} \mathrm{heater}(\mathrm{kg} / \mathrm{h})$

Mex6 : Laju aliran massa extraction steam ke HP\#6 heater $(\mathrm{kg} / \mathrm{h})$

$\mathrm{Mm}$ : Laju aliran massa make up water ke condenser $(\mathrm{kg} / \mathrm{h})$

Mds : deaerator tank storage $(\mathrm{kg} / \mathrm{h})$

Mcs : Condenser hotwell storage $(\mathrm{kg} / \mathrm{h})$

Mbd : Boiler Drum storage $(\mathrm{kg} / \mathrm{h})$

Gs2 : Laju aliran massa Control valve steam 2nd leak-off $(\mathrm{kg} / \mathrm{h})$

G11 : Laju aliran massa \#1 Gland 1st leak-off (kg/h)

G12 : Laju aliran massa \#1 gland 2nd leak-off $(\mathrm{kg} / \mathrm{h})$

G22 : Laju aliran massa \#2 gland 2nd leak-off (kg/h)

G23 : Laju aliran massa \#2 gland 3rd leak-off $(\mathrm{kg} / \mathrm{h})$

Hfw : Entalpi feed water $(\mathrm{kJ} / \mathrm{kg})$

$\mathrm{H} 2$ : Entalpi cold reheat steam $(\mathrm{KJ} / \mathrm{kg})$

$\mathrm{H} 3$ : Entalpi Hot reheat steam $(\mathrm{KJ} / \mathrm{kg})$ 


\section{METODE}

Metode yang digunakan untuk menghitung net plant heat rate PLTU Tanjung Jati B Unit 3 dan 4 adalah seperti pada Gambar 1 :

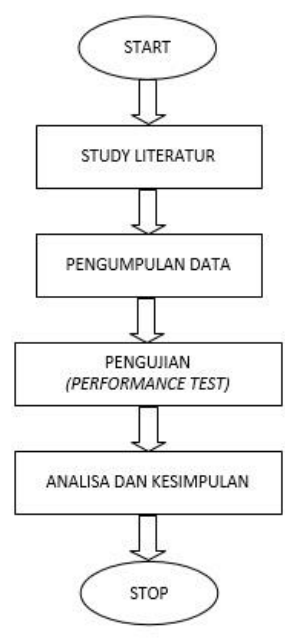

\section{Gambar 1. Diagram alir penelitian}

\section{Studi Literatur}

Metode ini dilakukan dengan membaca buku-buku sebagai referensi yang berupa manual book di Perpustakaan PLTU Tanjung Jati B dan buku heat rate handbook dari bagian perencanaan dan pengendalian operasi atau buku yang berkaitan dengan sistem pembangkit listrik tenaga uap, serta mencari sumber informasi lainnya sebagai dasar teori.

\section{Pengumpulan data}

Pengambilan data ditujukan untuk memperoleh parameter-parameter yang diperlukan dalam analisa. Pengambilan data harus dilakukan sesuai dengan prosedur. Pengambilan data dilakukan dengan cara sebagai berikut :

a. Untuk data-data yang masih tersimpan pada data base komputer DCS, data parameterparameter dapat secara langsung diambil.

b. Sedangkan untuk data-data yang sudah tidak tersimpan pada data Base komputer DCS, maka data parameter-parameter diambil dengan cara melihat data arsip pada bagian operasional.

\section{Pengujian (Performance Test)}

Pengujian (Performance Test) turbin uap dilakukan pada beban 660 MW (100\% load). Pengujian dilakukan dengan tujuan untuk mendapatkan data kinerja pembangkit terbaru.
Pengujian dilakukan dengan kondisi :

a. Kondisi Eksternal

Pengujian ini dilakukan 2 kali per-tahun pada kedua unit. Dan dilakukan pada dua musim yang berbeda. Pengujian pertama dilaksanakan pada pertengahan tahun saat musim kemarau dan pengujian kedua pada akhir tahun saat musim hujan. Hal ini untuk menjaga pengaruh variasi musim yang mungkin berpengaruh terhadap kadar kandungan air pada batu bara, temperatur udara (ambient temperature) dan kandungan air (moisture).

b. Kondisi Internal

Kondisi pengujian internal harus dilakukan sesuai standar pada masing-masing pengujian untuk memperoleh hasil pengujian yang dapat diandalkan dan diperbandingkan dari waktu ke waktu.

Hal-hal yang harus dilakukan sebelum pengujian antara lain :

1. Output generator harus sesuai dengan parameter pengujian dan terjaga kestabilannya yaitu pada $660 \mathrm{MW}$ net.

2. Operasi stabil

3. Kondisi turbin selama beroperasi harus pada mode normal. Dan selama proses pengujian, unit harus dijaga dalam kondisi aliran (flow) yang stabil, tekanan dan temperaturnya. Sehingga diperlukan setidaknya waktu selama 1 jam sebelum mulai untuk membuat kondisi ini. Proses Isolasi Keakuratan hasil pengujian tergantung pada isolasi dari sistem. Aliranaliran yang tidak diperlukan harus diisolasi dari sistem.

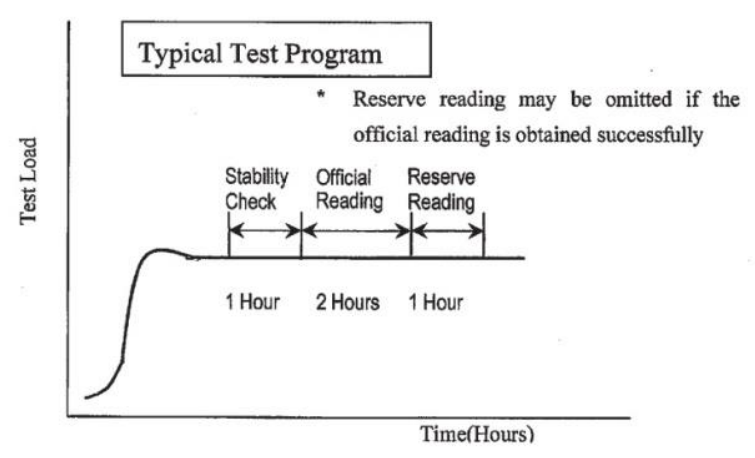

Gambar 2. Typical Test Program

4. Udara pembakaran boiler harus terkontrol pada kondisi yang optimum

5. Selama pengujian berlangsung jangan dihentikan atau mengganti komponen yang ada. 
Hal-hal yang dilakukan selama pelaksanaan pengujian yaitu :

a) Pengujian ini harus dilaksanakan selama 2 jam.

b) Interval pengambilan data dilakukan setiap 15 menit.

c) Sampel batu bara yang diambil dari masing-masing silo dilakukan sebanyak 3 , yaitu pada saat pengujian baru saja dimulai, setengah pengujian dan akhir pengujian. Dengan jumlah sampel masingmasing adalah $1 \mathrm{~kg}$.

d) Sampel fly ash yang diambil dari ESP A dan B pada field 1-4 dilakukan sebanyak tiga kali yaitu pada saat pengujian baru saja dimulai, setengah pengujian dan akhir pengujian dengan jumlah sampel masingmasing sebanyak 100 gram.

e) Pengambilan sampel bottom ash hanya dilakukan 1 kali segera setelah pengujian selesai sebanyak 100 gram dari bottom ash hopper.

f) Pengambilan sampel flue gas dilakukan pada inlet dan outlet air preheater sesaat setelah pengujian selesai, kemudian mencatat hasil analisa dari sampel probe.
4. Analisa dan Kesimpulan

Metode ini dilakukan pengolahan data yang telah didapatkan untuk menentukan nilai turbin heat rate. Dengan hasil tersebut dilakukan analisa deskriptif berdasarkan grafik dari hasil pengolahan data yang kemudian didapatkan kesimpulan.

\section{HASIL DAN PEMBAHASAN}

Data yang digunakan pada penelitian ini adalah data performance test pada saat mulai COD sampai dengan pelaksanaan performance test yang terakhir pada tahun 2019. Data parameter turbin heat rate untuk Unit 3 seperti terlihat pada Tabel 1. Dan untuk Unit 4 ditunjukkan pada Tabel 2.

Nilai turbin heat rate Unit 3 tertinggi sebesar $8.127 \mathrm{KJ} / \mathrm{kWh}$ terjadi pada performance test ke-11 dan terendah 7.764 $\mathrm{KJ} / \mathrm{kWh}$ terjadi pada performance test ke-6 seperti terlihat pada Tabel 1. Sedangkan pada Unit 4 nilai turbin heat rate tertinggi sebesar $8.117 \mathrm{KJ} / \mathrm{kWh}$ terjadi pada performance test ke12 dan terendah sebesar $7.978 \mathrm{KJ} / \mathrm{kWh}$ terjadi pada performance test ke-4 seperti yang ditunjukkan pada Tabel 2

Tabel 1. Data parameter turbin heat rate Unit 3

\begin{tabular}{|c|c|c|c|c|c|c|c|c|c|c|c|c|c|c|c|c|c|}
\hline \multicolumn{2}{|c|}{ Items } & Units & Design & $1^{\text {st }}$ Test & $2^{\text {nd }}$ Test & $3^{\text {rd }}$ Test & $4^{\text {th }}$ Test & $5^{\text {th }}$ Test & $6^{\text {th }}$ Test & $7^{\text {th }}$ Test & $8^{\text {th }}$ Test & $9^{\text {th }}$ Test & $10^{\text {th }}$ Test & $11^{\text {th }}$ Test & $12^{\text {th }}$ Test & $13^{\text {th }}$ Test & $14^{\text {th }}$ Test \\
\hline \multirow{5}{*}{ Main Steam } & Temperature & ${ }^{\circ} \mathrm{C}$ & 538 & 535 & 539 & 530 & 532 & 530 & 525 & 533 & 533 & 531 & 527 & 532 & 530 & 532 & $\overline{530}$ \\
\hline & Pressure & bara & 167 & 167 & 167 & 167 & 167 & 167 & 167 & 167 & 167 & 167 & 167 & 167 & 167 & 167 & 167 \\
\hline & Enthalpy & $\mathrm{kJ} / \mathrm{kg}$ & 3.399 & 3.389 & 3.401 & 3.375 & 3.381 & 3.377 & 3.360 & 3.385 & 3.384 & 3.377 & 3.368 & 3.381 & 3.375 & 3.383 & 3.377 \\
\hline & Flow & $\left(10^{3}\right) \mathrm{kg} / \mathrm{hr}$ & 2.124 & 2.183 & 2.198 & 2.210 & 2.211 & 2.201 & 2.117 & 2.217 & 2.207 & 2.221 & 2.229 & 2.207 & 2.186 & 2.197 & 2.215 \\
\hline & Heat input & $\left(10^{6}\right) \mathrm{kJ} / \mathrm{hr}$ & 7.217 & 7.399 & 7.474 & 7.459 & 7.475 & 7.431 & 7.114 & 7.505 & 7.469 & 7.503 & 7.508 & 7.461 & 7.379 & 7.430 & 7.482 \\
\hline \multirow{5}{*}{ Hot Reheat } & Temperature & ${ }^{\circ} \mathrm{C}$ & 538 & 546 & 543 & 543 & 542 & 547 & 543 & 541 & 546 & 544 & 543 & 548 & 547 & 542 & 542 \\
\hline & Pressure & bara & 35 & 36 & 37 & 37 & 37 & 37 & 37 & 37 & 37 & 37 & 37 & 37 & 37 & 37 & 37 \\
\hline & Enthalpy & $\mathrm{kJ} / \mathrm{kg}$ & 3.537 & 3.554 & 3.548 & 3.548 & 3.546 & 3.557 & 3.548 & 3.543 & 3.553 & 3.550 & 3.547 & 3.559 & 3.558 & 3.545 & 3.545 \\
\hline & Flow & $\left(10^{3}\right) \mathrm{kg} / \mathrm{hr}$ & 1.790 & 1.814 & 1.827 & 1.834 & 1.837 & 1.831 & 1.853 & 1.847 & 1.840 & 1.836 & 1.859 & 1.841 & 1.825 & 1.835 & 1.851 \\
\hline & Heat input & $\left(10^{6}\right) \mathrm{kJ} / \mathrm{hr}$ & 6.331 & 6.448 & 6.480 & 6.507 & 6.512 & 6.511 & 6.575 & 6.545 & 6.537 & 6.518 & 6.594 & 6.552 & 6.493 & 6.507 & 6.560 \\
\hline \multirow{5}{*}{ Final Feed Water } & Temperature & ${ }^{\circ} \mathrm{C}$ & 286 & 288 & 289 & 288 & 288 & 288 & 288 & 288 & 287 & 287 & 287 & 287 & 287 & 286 & 287 \\
\hline & Pressure & bara & - & 187 & 188 & 188 & 188 & 188 & 188 & 189 & 189 & 189 & 189 & 189 & 188 & 189 & 189 \\
\hline & Enthalpy & $\mathrm{kJ} / \mathrm{kg}$ & 1.261 & 1.275 & 1.278 & 1.275 & 1.275 & 1.272 & 1.271 & 1.270 & 1.269 & 1.268 & 1.268 & 1.267 & 1.267 & 1.264 & 1.266 \\
\hline & Flow & $\left(10^{3}\right) \mathrm{kg} / \mathrm{hr}$ & 1.999 & 2.170 & 2.179 & 2.202 & 2.204 & 2.187 & 2.106 & 2.207 & 2.200 & 2.214 & 2.219 & 2.200 & 2.168 & 2.192 & 2.209 \\
\hline & Heat Output & $\left(10^{6}\right) \mathrm{kJ} / \mathrm{hr}$ & 2.520 & 2.765 & 2.784 & 2.807 & 2.809 & 2.782 & 2.677 & 2.804 & 2.791 & 2.806 & 2.812 & 2.787 & 2.747 & 2.771 & 2.796 \\
\hline \multirow{4}{*}{ Cold Reheat } & Pressu & bara & - & 40 & 40 & 40 & 40 & 40 & 41 & 41 & 41 & 40 & 41 & 40 & 40 & 40 & 41 \\
\hline & Enthalpy & $\mathrm{kJ} / \mathrm{kg}$ & 3.026 & 3.048 & 3.058 & 3.040 & 3.044 & 3.042 & 3.030 & 3.050 & 3.049 & 3.042 & 3.037 & 3.045 & 3.039 & 3.046 & 3.042 \\
\hline & Flow & $\left(10^{3}\right) \mathrm{kg} / \mathrm{hr}$ & 1.790 & 1.814 & 1.827 & 1.834 & 1.837 & 1.831 & 1.853 & 1.847 & 1.840 & 1.836 & 1.859 & 1.841 & 1.825 & 1.835 & 1.851 \\
\hline & Heat Output & $\left(10^{6}\right) \mathrm{kJ} / \mathrm{hr}$ & 5.416 & 5.530 & 5.585 & 5.576 & 5.590 & 5.569 & 5.615 & 5.634 & 5.609 & 5.586 & 5.645 & 5.607 & 5.547 & 5.590 & 5.630 \\
\hline \multirow{4}{*}{ SH Spray } & Pressure & bara & - & 197 & 199 & 201 & 203 & 209 & 210 & 214 & 211 & 215 & 212 & 212 & 205 & 212 & 211 \\
\hline & Enthalpy & $\mathrm{kJ} / \mathrm{kg}$ & 731 & 742 & 743 & 743 & 744 & 745 & 746 & 746 & 746 & 747 & 747 & 745 & 744 & 744 & 746 \\
\hline & Flow & $\mathrm{kg} / \mathrm{hr}$ & 125.000 & 13.270 & 18.980 & 7.473 & 7.472 & 12.364 & 11.014 & 14.227 & 7.768 & 7.622 & 9.978 & 6.430 & 20.512 & 7.295 & 7.224 \\
\hline & Heat Output & $\left(10^{3}\right) \mathrm{kJ} / \mathrm{hr}$ & 91.400 & 9.850 & 14.095 & 5.556 & 5.556 & 9.206 & 8.211 & 10.614 & 5.792 & 5.691 & 7.450 & 4.793 & 15.266 & 5.428 & 5.386 \\
\hline \multicolumn{2}{|l|}{ Total Heat Input } & $\left(10^{6}\right) \mathrm{kJ} / \mathrm{hr}$ & 13.549 & 13.847 & 13.954 & 13.965 & 13.987 & 13.942 & 13.689 & 14.050 & 14.006 & 14.021 & 14.102 & 14.013 & 13.872 & 13.937 & 14.041 \\
\hline \multicolumn{2}{|l|}{ Total Heat Output } & $\left(10^{6}\right) \mathrm{kJ} / \mathrm{hr}$ & 8.027 & 8.306 & 8.383 & 8.389 & 8.404 & 8.361 & 8.300 & 8.449 & 8.406 & 8.397 & 8.465 & 8.399 & 8.309 & 8.367 & 8.431 \\
\hline \multicolumn{2}{|c|}{ Total Heat consumption } & $\left(10^{6}\right) \mathrm{kJ} / \mathrm{hr}$ & 5.521 & 5.542 & 5.571 & 5.577 & 5.583 & 5.582 & 5.389 & 5.601 & 5.600 & 5.624 & 5.637 & 5.614 & 5.563 & 5.570 & 5.610 \\
\hline \multicolumn{2}{|l|}{ Generator Output } & $\mathrm{kW}$ & 695.700 & 694.900 & 695.207 & 695.459 & 695.918 & 695.492 & 695.623 & 696.721 & 695.818 & 696.231 & 695.298 & 692.785 & 695.479 & 695.562 & 694.835 \\
\hline \multicolumn{2}{|l|}{ Excitation loss } & $\mathrm{kW}$ & 0 & 1.808 & 1.762 & 1.790 & 1.801 & 1.599 & 1.567 & 1.939 & 1.605 & 1.601 & 1.594 & 2.054 & 1.873 & 1.687 & 1.978 \\
\hline \multicolumn{2}{|l|}{ Gross Output } & $\mathrm{kW}$ & 695.700 & 693.092 & 693.444 & 693.669 & 694.117 & 693.893 & 694.056 & 694.783 & 694.213 & 694.630 & 693.703 & 690.731 & 693.606 & 693.875 & 692.857 \\
\hline \multicolumn{2}{|l|}{ Turbine Heat rate } & $\mathrm{kJ} / \mathrm{kWh}$ & 7.936 & 7.996 & 8.034 & 8.039 & 8.043 & 8.044 & 7.764 & 8.061 & 8.067 & 8.096 & 8.126 & 8.127 & 8.021 & 8.027 & 8.098 \\
\hline
\end{tabular}


Tabel 2. Data parameter turbin heat rate Unit 4

\begin{tabular}{|c|c|c|c|c|c|c|c|c|c|c|c|c|c|c|c|c|c|}
\hline \multicolumn{2}{|c|}{ Items } & Units & Design & $1^{\text {st }}$ Test & $2^{\text {nd }}$ Test & $3^{\text {tdd }}$ Test & $4^{\text {th }}$ Test & $5^{\text {th }}$ Test & $6^{\text {th }}$ Test & $7^{\text {th }}$ Test & $8^{\text {th }}$ Test & $9^{\text {th }}$ Test & $10^{\text {th }}$ Test & $11^{\text {th }}$ Test & $12^{\text {th }}$ Test & $13^{\text {th }}$ Test & $14^{\text {th }}$ Test \\
\hline \multirow{5}{*}{ Main Steam } & Temperature & ${ }^{\circ} \mathrm{C}$ & 538 & 536 & 541 & 539 & 531 & 536 & 532 & 536 & 535 & 529 & 533 & 531 & 534 & 527 & $\overline{532}$ \\
\hline & Pressure & bara & 167 & 167 & 167 & 167 & 167 & 167 & 167 & 166 & 167 & 167 & 167 & 167 & 167 & 167 & 167 \\
\hline & Enthalpy & $\mathrm{kJ} / \mathrm{kg}$ & 3.399 & 3.392 & 3.406 & 3.400 & 3.379 & 3.393 & 3.380 & 3.394 & 3.389 & 3.373 & 3.384 & 3.379 & 3.386 & 3.368 & 3.383 \\
\hline & Flow & $\left(10^{3}\right) \mathrm{kg} / \mathrm{hr}$ & 2.124 & 2.201 & 2.187 & 2.199 & 2.196 & 2.216 & 2.203 & 2.196 & 2.218 & 2.235 & 2.205 & 2.214 & 2.223 & 2.215 & 2.183 \\
\hline & Heat input & $\left(10^{6}\right) \mathrm{kJ} / \mathrm{hr}$ & 7.217 & 7.467 & 7.450 & 7.478 & 7.422 & 7.520 & 7.447 & 7.453 & 7.515 & 7.538 & 7.461 & 7.480 & 7.527 & 7.461 & 7.384 \\
\hline \multirow{5}{*}{ Hot Reheat } & Temperature & ${ }^{\circ} \mathrm{C}$ & 538 & 541 & 547 & 541 & 543 & 545 & 545 & 547 & 547 & 540 & 545 & 546 & 547 & 545 & 545 \\
\hline & & bara & 35 & 36 & 37 & 37 & 37 & 37 & 37 & 37 & 37 & 37 & 37 & 37 & 37 & 37 & 36 \\
\hline & Enthalpy & $\mathrm{kJ} / \mathrm{kg}$ & 3.537 & 3.544 & 3.556 & 3.544 & 3.548 & 3.552 & 3.551 & 3.556 & 3.556 & 3.540 & 3.552 & 3.554 & 3.555 & 3.551 & 3.551 \\
\hline & Flow & $\left(10^{3}\right) \mathrm{kg} / \mathrm{hr}$ & 1.790 & 1.825 & 1.822 & 1.824 & 1.820 & 1.837 & 1.825 & 1.820 & 1.840 & 1.849 & 1.831 & 1.839 & 1.855 & 1.842 & 1.821 \\
\hline & Heat input & $\left(10^{6}\right) \mathrm{kJ} / \mathrm{hr}$ & 6.331 & 6.468 & 6.478 & 6.464 & 6.459 & 6.527 & 6.483 & 6.472 & 6.541 & 6.546 & 6.504 & 6.535 & 6.594 & 6.540 & 6.466 \\
\hline \multirow{5}{*}{ Final Feed Water } & Temperature & ${ }^{\circ} \mathrm{C}$ & 286 & 291 & 291 & 291 & 290 & 291 & 291 & 290 & 291 & 290 & 290 & 289 & 289 & 289 & 288 \\
\hline & & bara & & 188 & 186 & 188 & 188 & 188 & 188 & 187 & 188 & 189 & 188 & 189 & 189 & 188 & 188 \\
\hline & Enthalpy & $\mathrm{kJ} / \mathrm{kg}$ & 1.261 & 1.287 & 1.288 & 1.286 & 1.283 & 1.286 & 1.285 & 1.284 & 1.286 & 1.284 & 1.280 & 1.279 & 1.278 & 1.278 & 1.273 \\
\hline & Flow & $\left(10^{3}\right) \mathrm{kg} / \mathrm{hr}$ & 1.999 & 2.189 & 2.136 & 2.186 & 2.184 & 2.208 & 2.191 & 2.195 & 2.204 & 2.238 & 2.195 & 2.206 & 2.194 & 2.194 & 2.160 \\
\hline & Heat Output & $\left(10^{6}\right) \mathrm{kJ} / \mathrm{hr}$ & 2.520 & 2.817 & 2.751 & 2.810 & 2.802 & 2.838 & 2.816 & 2.818 & 2.835 & 2.874 & 2.811 & 2.822 & 2.804 & 2.805 & 2.751 \\
\hline \multirow{4}{*}{ Cold Reheat } & & bara & - & 40 & 40 & 40 & 40 & 40 & 40 & 40 & 40 & 41 & 40 & 40 & 41 & 40 & 40 \\
\hline & Enthalpy & $\mathrm{kJ} / \mathrm{kg}$ & 3.026 & 3.050 & 3.063 & 3.057 & 3.042 & 3.054 & 3.042 & 3.053 & 3.050 & 3.038 & 3.046 & 3.043 & 3.050 & 3.034 & 3.046 \\
\hline & Flow & $\left(10^{3}\right) \mathrm{kg} / \mathrm{hr}$ & 1.790 & 1.825 & 1.822 & 1.824 & 1.820 & 1.837 & 1.825 & 1.820 & 1.840 & 1.849 & 1.831 & 1.839 & 1.855 & 1.842 & 1.821 \\
\hline & Heat Output & $\left(10^{6}\right) \mathrm{kJ} / \mathrm{hr}$ & 5.416 & 5.566 & 5.580 & 5.577 & 5.538 & 5.611 & 5.553 & 5.557 & 5.610 & 5.618 & 5.577 & 5.596 & 5.657 & 5.587 & 5.545 \\
\hline \multirow{5}{*}{ SH Spray } & Temperature & ${ }^{\circ} \mathrm{C}$ & - & 173 & 174 & 174 & 174 & 174 & 174 & 174 & 174 & 174 & 174 & 174 & 175 & 174 & 174 \\
\hline & Pressu & bara & - & 197 & 196 & 199 & 204 & 205 & 207 & 207 & 209 & 213 & 206 & 212 & 212 & 200 & 202 \\
\hline & Enthalpy & $\mathrm{kJ} / \mathrm{kg}$ & 731 & 744 & 746 & 745 & 746 & 749 & 747 & 748 & 750 & 750 & 748 & 749 & 751 & 748 & 747 \\
\hline & Flow & $\mathrm{kg} / \mathrm{hr}$ & 125.000 & 16.017 & 56.241 & 21.054 & 20.726 & 23.646 & 13.950 & 1.278 & 12.862 & 0 & 11.805 & 9.860 & 28.678 & 23.827 & 25.275 \\
\hline & Heat Output & $\left(10^{3}\right) \mathrm{kJ} / \mathrm{hr}$ & 91.400 & 11.923 & 41.966 & 15.695 & 15.468 & 17.701 & 10.427 & 955 & 9.640 & 0 & 8.834 & 7.390 & 21.532 & 17.817 & 18.876 \\
\hline \multicolumn{2}{|l|}{ Total Heat Input } & $\left(10^{6}\right) \mathrm{kJ} / \mathrm{hr}$ & 13.549 & 13.935 & 13.928 & 13.943 & 13.881 & 14.047 & 13.930 & 13.925 & 14.056 & 14.085 & 13.966 & 14.015 & 14.120 & 14.001 & 13.850 \\
\hline \multicolumn{2}{|l|}{ Total Heat Output } & $\left(10^{6}\right) \mathrm{kJ} / \mathrm{hr}$ & 8.027 & 8.395 & 8.373 & 8.403 & 8.356 & 8.467 & 8.380 & 8.376 & 8.454 & 8.492 & 8.397 & 8.425 & 8.482 & 8.409 & 8.315 \\
\hline \multicolumn{2}{|c|}{ Total Heat consumption } & $\left(10^{6}\right) \mathrm{kJ} / \mathrm{hr}$ & 5.521 & 5.540 & 5.555 & 5.540 & 5.525 & 5.580 & 5.550 & 5.549 & 5.601 & 5.593 & 5.568 & 5.589 & 5.638 & 5.591 & 5.535 \\
\hline \multicolumn{2}{|l|}{ Generator Output } & $\mathrm{kW}$ & 695.700 & 695.868 & 695.098 & 695.361 & 694.091 & 695.802 & 693.033 & 694.488 & 695.785 & 694.529 & 695.802 & 694.008 & 696.289 & 693.182 & 689.777 \\
\hline \multicolumn{2}{|l|}{ Excitation loss } & $\mathrm{kW}$ & 0 & 1.815 & 1.663 & 1.691 & 1.566 & 1.584 & 1.596 & 1.554 & 1.582 & 1.569 & 1.581 & 1.850 & 1.659 & 1.750 & 1.630 \\
\hline \multirow{2}{*}{\multicolumn{2}{|c|}{$\begin{array}{l}\text { Gross Output } \\
\text { Turbine Heat rate }\end{array}$}} & $\mathrm{kW}$ & 695.700 & 694.052 & 693.436 & 693.670 & 692.525 & 694.218 & 691.437 & 692.933 & 694.203 & 692.960 & 694.221 & 692.158 & 694.630 & 691.432 & 688.146 \\
\hline & & $\mathrm{kJ} / \mathrm{kWh}$ & 7.936 & 7.982 & 8.011 & 7.986 & 7.978 & 8.037 & 8.027 & 8.009 & 8.069 & 8.071 & 8.021 & 8.075 & 8.117 & 8.086 & 8.043 \\
\hline
\end{tabular}

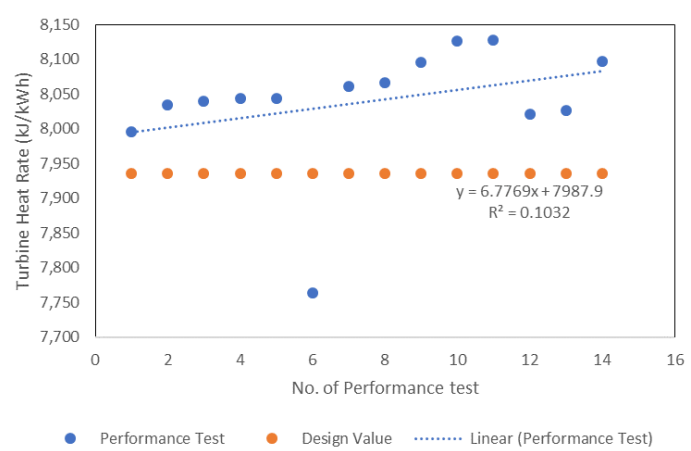

Gambar 3. Kenaikan turbine heat rate Unit 3

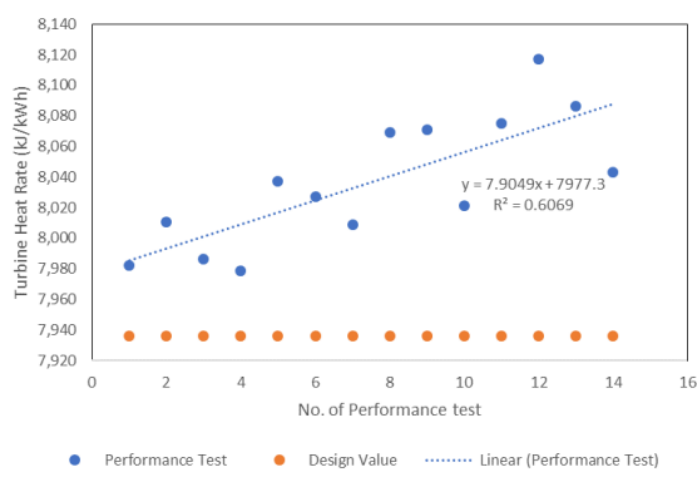

Gambar 4. Kenaikan turbine heat rate Unit 4

Metode regresi linear digunakan untuk memprediksi kenaikan turbin heat berdasarkan hasil penelitian Jangamshetti (2015). Dari hasil perhitungan seperti terlihat pada Tabel 1 dan dalam Gambar 3, nilai kenaikan turbin heat rate Unit 3 sebesar $6,77 \mathrm{KJ} / \mathrm{kWh}$ per-semester $(6$ bulan) atau 13,54 $\mathrm{KJ} / \mathrm{kWh}$ pertahunan. Sedangkan kenaikan turbin heat rate Unit 4 sebesar 7,90 KJ/kWh per semester atau 15,8 $\mathrm{KJ} / \mathrm{kWh}$ per-tahun seperti terlihat pada Tabel 2 dan Gambar 4.

\section{KESIMPULAN}

Dari hasil penelitian yang telah dilakukan dapat diambil kesimpulan sebagai berikut:

1. Turbin heat rate Unit 3 tertinggi sebesar $8.127 \mathrm{KJ} / \mathrm{kWh}$ dan terendah 7.764 $\mathrm{KJ} / \mathrm{kWh}$. Sedangkan pada Unit 4 nilai turbin heat rate tertinggi sebesar 8.117 $\mathrm{KJ} / \mathrm{kWh}$ dan terendah sebesar 7.978 $\mathrm{KJ} / \mathrm{kWh}$.

2. Dengan menggunakan metode regresi linear didapat perkiraan kenaikan turbin heat rate untuk Unit 3 sebesar 13,54 $\mathrm{KJ} / \mathrm{kWh}$ per-tahun dan untuk Unit 4 sebesar 15,8 KJ/kWh per-tahun.

\section{DAFTAR PUSTAKA}

A H Rana, (2013), Energy and Exergy Analysis of Extraction cum Back Pressure Steam Turbine, International Journal of Modern Engineering Research (IJMER), Vol.3, Issue.2, March-April. 2013 pp-626-632.

A Sinan Karakurt, (2017), Performance Analysis Of A Steam Turbine Power Plant At Part Load Conditions, Journal of Thermal Engineering, Vol. 3, No. 2, pp. 1121-1128. Arundhatee Dab, (2017), A Case Study on Heat Rate of Boiler and Turbine in NSPCL 
Durgapur, International Journal of Latest Technology in Engineering, Management \& Applied Science (IJLTEMAS), Volume VI, Issue VIII.

ASME, (2004), Steam Turbine Performance Test Codes 6.

C. C. L., D. S. Jangamshetti, and S. Sonoli, (2015), Boiler efficiency estimation from hydrogen content in fuel, International Conference on Advances in Computing, Communications and Informatics (ICACCI), pp. 1107-1110.
Jamaludin, (2017), Analisis Perhitungan Daya Turbin Yang Dihasilkan dan Efisiensi Turbin Uap pada Unit 1 dan Unit 2 di PT Indonesia Power UBOH UJP Banten 3 Lontar. Jurnal Universitas Muhammadiyah Tangerang. Vol 1 No.2 .

Sunarwo, (2015), Analisa Heat Rate pada Turbin Uap berdasarkan Performance Test PLTU Tanjung Jati B Unit 3, EKSERGI Jurnal Teknik Energi, Vol 11 No.3.

Toshiba, (2011), Performance Test Procedure for Turbine

Generator. 